\title{
Extraction of Kaempferol and Its Glycosides Using Supercritical Fluids from Plant Sources: A Review
}

\author{
Sandro Cid-Ortega ${ }^{1 *}$ \\ and José Alberto \\ Monroy-Rivera ${ }^{2+}$
}

\begin{abstract}
SUMMARY
Research has focused on the study and design of new products containing phytochemicals (polyphenolic acids, flavonoids and anthocyanins, among others) that contribute to a better life quality for consumers, as well as techniques to improve the extraction of these compounds. In this regard, extraction with supercritical fluids (usually $\mathrm{CO}_{2}$ ) is a technology that has better advantages than organic solvents, since lower temperatures that are used do not damage the product, and is more effective at high pressures. Extracts from plant sources contain significant concentrations of flavonols, one of the main compounds being kaempferol. Research has proven the antioxidant, anticarcinogenic, antidiabetic, cardioprotective, neuroprotective and antimicrobial properties of kaempferol and its glycosides. This review aims to present the main functional properties and extraction with supercritical fluids of kaempferol and its glycosides, as well as the application of this technology in the food area.
\end{abstract}

Key words: phytochemicals, flavonols, kaempferol, supercritical fluids

\section{INTRODUCTION}

The use of medicinal plants in Mexico is still important in traditional medicine for the treatment of various diseases among the population and these plants are also an important source for development of new medicines (1-3). The tendency to process foods with fewer artificial ingredients has become one of the main goals of the food and beverage industry. There is a great interest in the use of antioxidants from natural sources instead of synthetic ones in making foods and beverages, since besides acting as antioxidants, they may have functional and nutraceutical properties that help to prevent oxidative damage of cells in human body (4-6). Extraction of compounds from plant sources using supercritical $\mathrm{CO}_{2}$ for the production of food, beverages, drugs and fragrances is on the increase due to the quality and purity of obtained extracts, and because it is a technology that does not generate toxic waste. In food industry, the most important applications of this technology are extraction of hops and decaffeination of coffee; however, production of extracts rich in biologically active substances such as antioxidants, fat-soluble vitamins, pigments and others, is increasing very fast. Currently, there are more than 200 industries that are applying this technology around the world (7).

The extraction of kaempferol and its derivatives from plant sources (Justicia spicigera, Pteridium aquilinum, Acacia nilotica, Rosa rugosa Thunb, Moringa oleifera, Tilia americana var. Mexicana, Lycium barbarum, Diospyros kaki L., Camellia sinensis, to mention a few), by using solvents (mainly methanol, ethanol, acetone and water) and different extraction methods (extraction assisted with ultrasound, microwaves, ultrasound and microwaves, and simple extraction) has been investigated in several works (8-16). Also, these flavonoids (mainly kaempferol and kaempferitrin) have proven antidiabetic $(17,18)$ and anticancer (19) properties. However, there is little information about the extraction of kaempferol and its glycosides using supercritical fluids, with $\mathrm{CO}_{2}$ being the most used, since it has advantages over commonly used organic solvents, such as: it is non-flammable, non-toxic, non-carcinogenic, non-corrosive, does not generate waste, and it remains in a state with 
intermediate properties between liquid and gas under conditions of pressure and temperature above its critical point, making it an effective solvent. In addition, it is suitable for natural compound extraction with low volatility and polarity, and extract recovery is much easier due to high volatility of $\mathrm{CO}_{2}$. Another advantage of supercritical extraction process with $\mathrm{CO}_{2}$ is that it is carried out at relatively low temperatures and in the absence of light and oxygen, which prevents the degradation of labile compounds and reduces oxidative reactions $(20,21)$.

On the other hand, the main disadvantages of this technology are expensive equipment, the application of high critical pressures and low dielectric constant, which suggests low solvent power (22). Dielectric constant is one of the most important physicochemical properties to predict solubility in a particular fluid. Together with supercritical $\mathrm{CO}_{2}$ density, it increases with pressure. In a very dense state (200 bar and 40 ${ }^{\circ} \mathrm{C}$ ), dielectric constant of $\mathrm{CO}_{2}$ is about 1.5 , therefore, it can be compared with a very non-polar solvent, suitable for dissolving non-polar compounds. The key physicochemical property of a supercritical fluid is its density, which depends on the experimental conditions of pressure and temperature. This property directly influences dielectric constant and viscosity; in turn, intrinsic properties (density, viscosity and dielectric constant) decisively influence the capacity of fluid as a solvent, as well as diffusivity (23). Supercritical fluids have a viscosity 5 to 30 times lower than liquids and have a surface tension almost null. This implies two very important aspects, first that compounds spread more easily in a supercritical fluid than in liquid phases, and second, their penetrability in the porous materials is much higher (24). As pressure increases, carbon dioxide density increases and the average intermolecular distance of carbon dioxide molecules decreases, which leads to a better interaction between solute and solvent molecules (22). The use of co-solvents (mainly ethanol due to its low toxicity) has been suggested to increase polarity and selectivity of supercritical $\mathrm{CO}_{2}$ and to substantially improve polar compound extraction, mainly phenols, flavonoids and terpenoids $(25,26)$. This article presents a review of the most important properties of kaempferol and its glycosides, as well as the importance of the main variables in their extraction with supercritical fluids. Furthermore, some applications of this extraction technology in food production are mentioned, and finally, the relevance of the extraction with supercritical fluids of bioactive compounds from vegetal sources in the development of functional foods is discussed.

\section{FUNCTIONAL PROPERTIES OF KAEMPFEROL AND ITS GLYCOSIDES}

Flavonoids are polyphenolic compounds that are found in fruits, vegetables, leaves and flowers, and represent the most abundant secondary metabolites in nature. According to their structure, they can be classified into chalcones, flavonols, flavanonols, flavones, flavanols, flavanones, anthocyanins, aurones, isoflavones and phlobaphenes; flavonols (quercetin, kaempferol, myricetin and galangin, among others) being the most common in the plant kingdom $(27,28)$. The ability of flavonoids to be effective antioxidants generally depends on three factors: the chelation potential of metal that depends strongly on the arrangement of hydroxyl and carbonyl groups around the molecule, the presence of hydrogen-donating substituents or electrons able to reduce free radicals, and the ability of flavonoid to remove the unpaired electron, leading to the formation of a stable phenoxyl radical (29).

In the plant kingdom, flavonols are commonly found as glycosides. The most important kaempferol glucosides are astragalin (kaempferol-3-O-glucoside) and kaempferitrin (kaempferol-3,7-dirhamnoside). Several reports suggest that a high intake of foods rich in kaempferol might reduce the risk of developing several types of cancer (for example, lung, gastric, pancreatic and ovarian cancer), as well as cardiovascular diseases $(30,31)$.

\section{Antioxidant and anticancer properties}

Cancer is one of the leading causes of morbidity and mortality around the world; in 2012 there were 14 million new cases of cancer worldwide, of which 8 million (57\%) were in economically developed countries $(32,33)$. Cancer is the second leading cause of death worldwide, in 2015 it caused 8.8 million deaths and the incidence of cancer is expected to increase by about $70 \%$ in the next 20 years. An important aspect that stands out is the economic impact, it is estimated that economic cost of cancer in 2010 was approx. US\$ 1.16 trillion (33). About a third of cancer deaths are due to behavioural and dietary risk factors, mainly overweight, low fruit and vegetable intake, lack of physical activity, tobacco and alcohol use (33). Fig. 1 shows the most common types of cancer, lung cancer being the most deadly.

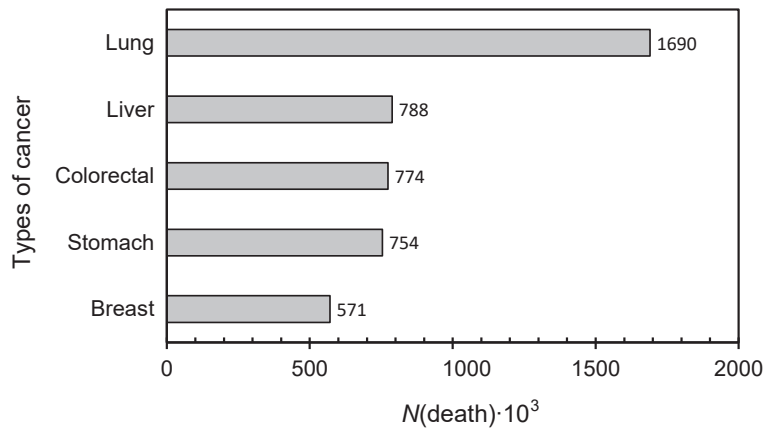

Fig. 1. Types of cancer that cause a greater number of deaths (33)

Oxidative stress plays a key role in the occurrence of cancer and other health problems induced by excess production of reactive oxygen species (ROS), which include many radicals such as superoxide $\left(\mathrm{O}^{2-}\right)$, hydroxyl $\left(\mathrm{OH}^{-}\right)$, hydroperoxyl $\left(\mathrm{OOH}^{-}\right)$, peroxyl ( $\left.\mathrm{ROO}^{-}\right)$, alkoxyl $\left(\mathrm{RO}^{-}\right)$, nitric oxide $\left(\mathrm{NO}^{-}\right)$and peroxynitrite anion ( $\left.\mathrm{ONOO}^{-}\right)$. These ROS may cause oxidative damage to vital biomolecules, such as DNA, lipids and proteins (32). 
The anticancer effects of flavonoids (flavonols, flavanols, anthocyanins, flavanones and isoflavones) have been studied in animals and in vitro assays, and they have been attributed to the ability of these compounds to inhibit cell cycle, cell proliferation and oxidative stress, as well as to induce enzyme detoxification and apoptosis. It has been proven that kaempferol uses different mechanisms for cancer cell regulation, inducing apoptosis and modifying a series of cellular signalling pathways (signal transduction) in cancer cells. Furthermore, several studies show the kaempferol efficacy to reduce cancer angiogenesis, both in vitro and in vivo, by inhibiting secretion of vascular endothelial growth factor in human cancer cell lines (34). However, evidence from human population studies is limited. Pancreatic cancer is one of the most fatal cancers; smoking can induce it but it is not the only risk factor (the diet, age, inherited genetic changes, among others, influence the development of pancreatic cancer). In the United States, a study (35) was conducted in Hawaii and Los Angeles, California, from 1993 to 1996, in which 183518 men and women aged between 45 and 75 took part. The main purpose of that work was to investigate the lifestyle of the participants, focusing on their diet and the relation to the incidence of pancreatic cancer (by multivariate Cox regression). They considered the intake of three flavonols: quercetin, kaempferol and myricetin. Diet was assessed by using a comprehensive quantitative food frequency questionnaire. Results showed that the intake of total flavonols was associated with a reduced pancreatic cancer risk. Of the three flavonols, kaempferol was associated with the highest risk reduction. In conclusion, the study provides evidence of a preventive effect of flavonols on pancreatic cancer, mainly for smokers. However, further epidemiologic studies are needed in other populations and geographic regions to confirm these findings.

Alonso-Castro et al. $(19,36)$ evaluated the antitumour and immunomodulatory effects of the ethanolic extract of Justicia spicigera in cancer cells (HeLa), as well as the mechanism of protective effect of the main component (kaempferitrin) of the extract. Results showed a tumour growth inhibition by $53 \%$, which indicates that J. spicigera might be an important source of antitumour compounds, kaempferitrin being the major component in the extract $(12.75 \mathrm{mg} / \mathrm{g})$. Moreover, extract of J. spicigera exerted low toxic effects in vitro and in vivo, and high toxic effects in vitro and in vivo against HeLa cells and immunomodulatory activities in vitro. Likewise, it was observed that the flavonoid kaempferitrin showed the highest cytotoxic effects against HeLa cells $\left(\mathrm{IC}_{50}=45 \mathrm{mM}\right)$ and it induced death in these cells by apoptosis. Therefore, J. spicigera extracts could be a potential source for anticancer drug production due to their low toxicity, antitumour effects and immunomodulatory activities.

In another study (37), the antiproliferative and cytotoxic effects of hydroalcoholic extract of Justicia spicigera in the androgen-dependent stage of prostate cancer (LNCaP cells) were evaluated. The qualitative analysis of secondary metabolites of the extracts at concentrations from 62.5 to $4000 \mu \mathrm{g} /$
$\mathrm{mL}$ showed the presence of coumarins, anthraquinones, flavonoids, sapogenins, sterols and steroids. Based on the results, authors suggest that cytostatic activity was the main antiproliferative mechanism of the extract against LNCaP prostate cancer cells. Proliferation of LNCaP cells incubated with the highest concentration of the extract was inhibited by approx. $(62 \pm 1.7) \%$. Prooxidant and antioxidant effects of kaempferol have also been studied. Marfe et al. (38) showed that a concentration of $50 \mathrm{mM}$ of kaempferol could induce apoptosis in human cell lines K562 (chronic myelogenous leukaemia) and U937 (promyelocytic leukaemia). These results are of major significance, since kaempferol might be in use in the treatment of leukaemia with both direct inhibitory effects and enhancing the effects of other chemotherapies with low toxicity.

Quercetin and kaempferol are the most common flavonols found in the vegetables for human consumption. A synergistic effect of these compounds has been suggested in reduction of cancer cells. Ackland et al. (39) showed the synergistic effect of quercetin and kaempferol on cell proliferation reduction of human colon cancer gut lines (Caco-2) and duodenum (HuTu-80), as well as PMC42 breast cancer cell line. Cells were treated with a single 4-day or 14-day exposure to quercetin, kaempferol and a mixture of these, at concentrations of 1,5 and $10 \mu \mathrm{M}$. A cell reduction was observed in all treatments with a single exposure (single dose). However, greatest reduction in total gut cell count (Caco-2 and HuTu-80) was observed when applying combined quercetin/kaempferol treatment at $10 \mu \mathrm{M}$, reducing the cell number by $74 \%$ in $72 \mathrm{~h}$. Significant reductions in cell counts of PMC42 breast cancer cells were reached after $72 \mathrm{~h}$ of treatment with $5 \mu \mathrm{M}$ quercetin, $10 \mu \mathrm{M}$ kaempferol, or combined quercetin/kaempferol treatment both at $10 \mu \mathrm{M}$. The most effective treatment was $10 \mu \mathrm{M}$ kaempferol, with an $18 \%$ reduction in cell number compared to control cells. With respect to treatment for 4 days, the greatest reduction (34\%) of HuTu80 cells was achieved with combined quercetin/kaempferol treatment at $5 \mu \mathrm{M}$. For Caco-2 cells, the greatest reduction was by $38 \%$ using combined quercetin/kaempferol treatment both at $10 \mu \mathrm{M}$. Regarding PMC42 breast cancer cells, the one that showed the greatest reduction in cell count (by $39 \%$ ) was combined quercetin/kaempferol treatment, both at $5 \mu \mathrm{M}$. This corresponds to approx. 4-fold higher inhibition in cell number than with the addition of quercetin and kaempferol alone at concentration of $5 \mu \mathrm{M}$, indicating a possible synergistic response of these compounds. In the 14-day treatment, HuTu-80 cell count had the greatest reduction (by $21 \%)$ using $10 \mu \mathrm{M}$ kaempferol and by $42 \%$ of Caco- 2 cells in a combined quercetin/kaempferol treatment at $10 \mu \mathrm{M}$. Once again, greater inhibition was observed when using combination of quercetin and kaempferol than when using single flavonol, indicating a possible synergistic effect. Reduction in cell proliferation of PMC42 breast cancer cells (17\%) was more effective in the combined treatment at $1 \mu \mathrm{M}$. Total protein evaluations (Ki67) on HuTu-80 and Caco-2 gut cells following a 
single exposure to quercetin and kaempferol indicated a reduction of total protein levels, but at a lower rate regarding cell counts. Based on the obtained results, authors (39) conclude that the addition of combined flavonols, quercetin and kaempferol, had a greater effect on the reduction of cell proliferation in two gut cancer cell lines (Caco-2 and HuTu-80) and PMC42 breast cancer cell line than quercetin or kaempferol added alone.

Luo et al. (40) evaluated the ability of kaempferol to induce apoptosis in A2780/CP70, A2780/wt and OVCAR-3 ovarian cancer cell lines, as well as the pathway involved in these apoptotic effects. Cell proliferation assay was performed by seeding ovarian cancer cells in 96-well plates at 2000 cells per well and incubated overnight before treatment with kaempferol $(0-160 \mu \mathrm{M})$ for $24 \mathrm{~h}$. For cytotoxicity evaluation, ovarian cancer cells were seeded in 96-well plates with 5000 cells per well, incubated overnight and treated with $100 \mu \mathrm{L}$ kaempferol for $24 \mathrm{~h}$. Apoptosis assay was performed on A2780/ CP70 ovarian cancer cells seeded in 96-well plates with 10000 cells per well, incubated overnight and treated with 0 or 80 $\mu \mathrm{M}$ kaempferol for 0, 2, 4 and $8 \mathrm{~h}$. For caspase- 9 inhibition trial, OVCAR-3 cells were seeded in 96-well plates at 10000 cells per well and incubated overnight. Cells were treated with a caspase-9 inhibitor (Z-LEHD-FMK; 0-10 $\mu \mathrm{M}$ ) or $10 \mu \mathrm{M}$ negative control (Z-FA-FMK) for $24 \mathrm{~h}$, and with kaempferol ( 0 or 80 $\mu \mathrm{M})$ for $2 \mathrm{~h}$. For Western blot test (technique to identify specific proteins in a complex mixture), ovarian cancer cells were seeded in 60-mm dishes, incubated overnight and treated with kaempferol $(0-80 \mu \mathrm{M})$ for $24 \mathrm{~h}$. It was observed that kaempferol at $40 \mu \mathrm{M}$ or greater concentrations inhibited significantly proliferation in a concentration-dependent manner in the three ovarian cancer cells tested. Apoptosis assay showed that a 2-hour kaempferol treatment could provide the best response in caspase- 3 and -7 activities (caspases are essential mediators of apoptosis processes) in A2780/CP70 cells. Apart from that, significantly high levels of caspase- 3 and -7 were observed at $80 \mu \mathrm{M}$ kaempferol treatment of the three cancer cell lines. Since pretreatment with a caspase-9 inhibitor significantly decreased apoptosis induced by kaempferol in OVCAR-3 cells, this suggests that kaempferol induces apoptosis through an intrinsic pathway in ovarian cancer cells. Apoptosis or programmed cell death is an essential cellular process for development and homeostasis maintenance (self-regulation) of adult tissues, and its main objective is to eliminate superfluous, damaged, infected or transformed cells (41). Therefore, authors suggest that apoptosis mechanism induced by kaempferol in ovarian cancer cells is performed by inhibiting the Akt protein phosphorylation (also called protein kinase $B$, which is an antiapoptotic factor that promotes cell proliferation, growth and survival, as well as tumour formation), which, in turn, inhibits $\mathrm{BCl}-\mathrm{xL}$ gene expression, but positively regulates the expression of $\mathrm{p} 53$, Bad and Bax genes, which cause an imbalance between the proapoptosis and antiapoptosis, favouring activation of caspase- 3 and -7 , as well as the intrinsic apoptosis. In conclusion, these characteristics make kaempferol an appropriate agent for ovarian cancer chemoprevention.

Choi and Ahn (42) investigated kaempferol effects on cell proliferation and apoptosis, as well as the mechanism of these effects in human breast carcinoma MDA-MB- 453 cells. Cells were treated with kaempferol $(0.1 \%$ solution in dimethyl sulfoxide) at various concentrations (0, 1, 5, 10, 50, 100, 150 and 200 $\mu \mathrm{M})$ for 24 and $48 \mathrm{~h}$. Inhibition of MDA-MB-453 cells showed significant differences beginning at concentrations of 10 and $50 \mu \mathrm{M}$ kaempferol after 48 and $24 \mathrm{~h}$, respectively, compared with controls. This cell cycle inhibition is generated in G2/M phase, through a down-regulation of CDK1 in MDA-MB-453 cells. Furthermore, a higher percentage of apoptosis was observed at sub-G0 phase exposed to kaempferol. Compared with vehicle-treated cells ( $3.10 \%)$, the apoptotic cells exposed to kaempferol had 23.12 and $31.90 \%$ of the cell population at 10 and $50 \mu \mathrm{M}$ for 24 and $48 \mathrm{~h}$, respectively. The p53 activation is involved in the coordinated antiproliferative effects, including effects on cell cycle and apoptosis. Results of that study show that kaempferol increased $p 53$ expression and clearly induced its phosphorylation in serine 15 . Thus, kaempferol-induced apoptosis may be related to phosphorylation mediated by the accumulation of $\mathrm{p} 53$ at serine 15 residues. Therefore, the authors suggest the existence of multiple pathways through which kaempferol stops the cell cycle in the G2/M phase, such as downregulated CDK1 and apoptotic cell death by modulating the p53 pathway. Hence, anticancer activity of kaempferol may be useful for developing anticancer drugs.

\section{Hypoglycaemic properties}

Chronic and degenerative diseases (mainly cardiovascular, cancer, diabetes and mental disorders) are responsible for $60 \%$ of deaths worldwide. Two of these, hypertension and diabetes mellitus type 2 , have been considered global pandemics (43). The number of people with diabetes in 1980 was 108 million and by the year 2014 it increased to 422 million. It was estimated that in 2015 diabetes was the direct cause of 1.6 million deaths and in accordance with projections by World Health Organization (WHO), diabetes will be the seventh cause of mortality in 2030 (44). Therefore, research has been conducted on plant extracts with the aim of establishing hypoglycaemic effects, as well as active compounds responsible for generating such effect. In Mexico, there is a great diversity of plants that are used in traditional medicine $(2,45)$.

The hypothesis that consumption of flavonoids reduces blood glucose levels has been proven in several animal models $(16,46,47,48)$. These substances are capable of improving, stabilizing and sustaining for long periods the insulin secretion, human islets and pancreatic cells. However, one of the main problems of these compounds is their poor solubility and stability under the influence of oxygen, light and temperature; consequently, their bioavailability is diminished $(16,47)$. An alternative to this problem is the encapsulation of target compound (flavonoid) by using polymers or emulsions. This process, in addition to improving flavonoid solubility, also improves its 
antioxidant capacity $(16,49,50)$. Apart from their antioxidant effect, flavonoids are able to affect the biological targets involved in diabetes mellitus type 2 , such as a-glucosidase and DPP-4 (dipeptidyl peptidase-4).

In a study conducted by de Sousa et al. (48), the blood glucose decrease in normal, hyperglycemic and alloxan-induced male Wistar rats $(60 \mathrm{mg} / \mathrm{kg})$ using kaempferitrin at 50 , 100 and $200 \mathrm{mg} / \mathrm{kg}$ was evaluated. All the animals were maintained with pelleted food and tap water available ad libitum. Kaempferitrin was obtained and purified from alcoholic extract of Bauhinia forficata leaves. Results showed a significant glucose level reduction in diabetic rats at all studied doses, but mainly at 100 and $200 \mathrm{mg} / \mathrm{kg}$, compared to time zero. The highest hypoglycaemic effect was found $2 \mathrm{~h}$ after treatment with kaempferitrin. It is concluded that purified kaempferitrin from $n$-butanol fraction of $B$. forficata leaves was effective in decreasing blood glucose levels in normal and diabetic rats. Furthermore, kaempferitrin from $n$-butanol fraction showed a strong antioxidant potential, since it inhibited lipid peroxidation in vitro in different lipid bilayers, indirectly demonstrating that different tissues, containing membranes of different lipid composition, can be protected. This may be of particular importance in some pathological conditions, including diabetes. Kaempferitrin also inhibits a prooxidant enzyme (myeloperoxidase) that plays a central role in infection and inflammation by converting hydrogen peroxide and chloride into hypochloric acid $(\mathrm{HOCl})$. $\mathrm{HOCl}$ has an important role in killing microorganisms, but it also possesses high reactivity and capacity to damage biomolecules by oxidation, both directly and in its decomposed form, chlorine gas $\left(\mathrm{Cl}_{2}\right)(48)$.

Ortiz-Andrade et al. (51) reported similar results when evaluating the cytotoxic, antioxidant and antidiabetic properties of alcoholic extract of Justicia spicigera at different mass fractions $(10,50$ and $100 \mathrm{mg} / \mathrm{kg})$ in male Wistar rats. Reference drugs used were gibenclamide $(10 \mathrm{mg} / \mathrm{kg})$, repaglinide $(4 \mathrm{mg} /$ $\mathrm{kg}$ ) and saxagliptin $(10 \mathrm{mg} / \mathrm{kg})$. J. spicigera extract significantly reduced plasma glucose in rats with normal glucose levels when administered orally, from 0.5 up to $4 \mathrm{~h}$ after administration, with an average decrease of $27.7 \%$ compared to the reference group. The highest glucose reduction was obtained with the mass fraction of $100 \mathrm{mg} / \mathrm{kg}$, showing a decrease of $27 \%$ in $1 \mathrm{~h}, 39.5 \%$ in $2 \mathrm{~h}$ and $45.8 \%$ in $3 \mathrm{~h}$. In streptozocin-induced diabetic rats, the extract $(100 \mathrm{mg} / \mathrm{kg}$ ) significantly reduced blood glucose levels, disclosing a decrease of $155 \%$ in $0.5 \mathrm{~h}$ and $185 \%$ in $1 \mathrm{~h}$. Moreover, extract antioxidant capacity for ABTS radical was $71 \%$ at a maximum concentration of 800 $\mu \mathrm{g} / \mathrm{mL}$ with $\mathrm{EC}_{50}$ value (effective average concentration) 180 $\mu \mathrm{g} / \mathrm{mL}$. For DPPH radical it was $81 \%$ at the same concentration $(800 \mu \mathrm{g} / \mathrm{mL})$ with $\mathrm{EC}_{50}$ value $100 \mu \mathrm{g} / \mathrm{mL}$. In conclusion, J. spicegera ethanolic extract (with kaempferitrin as the main component at a mass fraction of $69.65 \mathrm{mg} / \mathrm{g}$ ) stimulates glucose uptake in insulin-sensitive and insulin-resistant adipose cells, exerts antioxidant effects, and decreases glucose levels in rats with normal glucose levels, as well as in streptozotocin-induced diabetic rats.
In another study, Da Silva et al. (18) used the aqueous extract of Sedum dendroideum leaves (known in Mexico commonly as 'siempreviva') to investigate the in vivo hypoglycaemic activity of extract and its main flavonoids (kaempferol-3,7-dirhamnoside or kaempferitrin, kaempferol-3-glucoside-7-rhamnoside and kaempferol-3-neohesperidoside-7-rhamnoside) in normal and streptozotocin-induced diabetic mice. The aqueous extract, flavonoid-enriched fraction and kaempferitrin were used at mass fractions of 400,40 and $4 \mathrm{mg} / \mathrm{kg}$, respectively. Glucose level reduction in mice after $2 \mathrm{~h}$ was 52,53 and $60 \%$ when treated with aqueous extract, flavonoid-enriched fraction and kaempferitrin, respectively. Results showed that the extract had a hypoglycaemic potential both in diabetes mellitus type 1 and type 2. According to authors, hypoglycaemic activity of the extract is probably due to flavonol kaempferitrin and its rhamnosyl units at positions 3 and 7 of flavonoid skeleton. This flavonol also stimulates the glucose-metabolising enzymes (phosphofructokinase) reducing its activity, mainly in the liver.

One of the main glucose transporters in the body is GLUT4 (glucose transporter 4), which is found mainly in insulin-sensitive tissues, such as muscle and adipocytes. The decrease in intracellular concentrations of GLUT4 results in a state of insulin resistance (inadequate uptake of insulin-dependent glucose by tissues, especially liver, muscle and adipose tissue). By contrast, the increase in insulin sensitivity is mediated by the increase in translocation of GLUT4 towards plasma membrane; this favours glucose movement from the blood to the inside of the tissues (52). It has been reported that kaempferitrin (obtained from Bauhinia acuminata extract) could interact with GLUT4, causing a decrease in glucose absorption in adipocytes (53). Results of that research suggest that this effect is a consequence of at least two mechanisms: the first one by means of an interference with insulin activation route that produces a lower GLUT4 translocation and glucose absorption, and the second by interacting directly with GLUT4, competing with glucose for transport.

Flavonoid effectiveness as antioxidants and antidiabetics has been related to their structure. The aglycones (flavonoids that lack sugar) have an antioxidant action higher than their respective glycosides. Flavonoids with hydroxyl substituents in C-3' and C-4' carbons corresponding to B ring (Fig. 2) (54) have a higher antioxidant capacity and this is increased by the presence of a double bond between carbons C-2 and C-3, a hydroxyl group at the carbon C-3 and a carbonyl group at the carbon C-4 position (55).

Sarian et al. (54) investigated some isolated flavonoids from Tetracera indica and Tetracera scandens (plants traditionally used to control diabetes mellitus in different parts of Malaysia), with the aim of identifying key positions in their structure, the effect of methylation and acetylation, and their relationship with antioxidant and antidiabetic properties. Fourteen compounds with three structural variations of flavonoids were identified: flavones (absence of hydroxyl group at position 3: wogonin, methyl ether of wogonin, acetate of wogonin, techtochrysin, 8-hydroxy-7-methoxy flavone, chrysin, norwo 
<smiles>CC1C=C(c2ccccc2)Oc2ccccc21</smiles>

Fig. 2. Basic structure of flavonoids, adapted from Sarian et al. (54)

gonin, acetate of norwogonin, isoscutellarein and hypolaetin), flavonols (presence of hydroxyl group at position 3: kaempferol and quercetin) and flavanols (absence of double bond and ketonic group at positions 2-3 and 4, respectively: (+)-catechin and (-)-epicatechin). According to antioxidant capacity assays (using DPPH, ABTS, FRAP and xanthine oxidase) and the evaluation of antidiabetic properties (inhibition of a-glucosidase and dipeptidyl peptidase IV (DPP-4)), the best results were obtained with quercetin, isoscutellarein, hypolaetin and kaempferol. This confirms that total number and configuration of hydroxyl groups play an important role in the regulation of antioxidant and antidiabetic properties. The presence of a double bond between C-2 and C-3 and a ketonic group at C- 4 are two essential structural characteristics responsible for bioactivity of flavonoids, especially for antidiabetic property. Moreover, methylation and acetylation of hydroxyl groups decrease antioxidant and antidiabetic properties of flavonoids in vitro.

\section{Antidepressant properties}

The antidepressant effect of flavonol kaempferitrin obtained from Justicia spicigera (Asteraceae) extract, which is a plant used in traditional medicine to relieve emotional disorders (such as depression (dysthymia) and mood changes) and anxiety has been studied (56). The study was carried out applying two depression behaviour models in mice: tail suspension tests (TST) and forced swimming tests (FST). Antidepressant effect shown by kaempferitrin (10 and $20 \mathrm{mg} / \mathrm{kg}$ ) in TST was similar to that observed for positive control drugs (imipramine, fluoxetine and desipramine). In FST, mass fractions of 5,10 and $20 \mathrm{mg} / \mathrm{kg}$ kaempferitrin showed a significant

a)<smiles>O=c1c(O)c(-c2ccc(O)cc2)oc2cc(O)cc(O)c12</smiles>

reduction in immobility time. In conclusion, results show that kaempferitrin induces an effect similar to antidepressant, without producing alterations in ambulatory activity of experimental animals. However, it is necessary to carry out further experiments to determine the specific mechanisms underlying the actions of kaempferitrin.

Similar results were obtained by Hosseinzadeh et al. (57), when assessing the antidepressant effect of kaempferol from Crocus sativus (saffron flower) petals in mice (albinos) and rats (Wistar) by FST. Fluoxetine $(20 \mathrm{mg} / \mathrm{kg}$ ) was used as a positive control, while kaempferol (standard substance from Sigma-Aldrich, St. Louis, MO, USA) was used at mass fractions of $25,50,100$ and $200 \mathrm{mg} / \mathrm{kg}$ for mice and 12.5, 25 and $50 \mathrm{mg} /$ $\mathrm{kg}$ for rats. Results of that study indicated that kaempferol (100 and $200 \mathrm{mg} / \mathrm{kg}$ in mice and $50 \mathrm{mg} / \mathrm{kg}$ in rats) had an antidepressant effect, and hence it can be a helpful agent in the treatment of depression.

\section{EXTRACTION OF KAEMPFEROL AND ITS GLYCOSIDES BY SUPERCRITICAL FLUIDS}

Kaempferol (3,4',5,7-tetrahydroxyflavone) (Fig. 3a) is a flavonol first discovered in Camellia sinensis (commonly known as green tea) (16). This compound is found in a wide variety of fruits and vegetables (apples, apricots, asparagus, blackberries, broccoli, capers, carrots, cherries, cranberries, cucumbers, grapes, kiwifruit, lemon, lettuce, cantaloupe melon, onions, oranges, peaches, plums, raisins, saffron, spinach and green tea) (16). Kaempferitrin (kaempferol-3,7-O-(a)-L-dirhamnoside) (Fig. 3b) is a glucoside derived from kaempferol, which was isolated for the first time from Indigo arrecia (17). The main sources of this compound are some plants belonging to the division Magnoliophyta: Lespedeza cyrtobotrya, Lespedeza virgata, Bauhinia acuminata, Pterogyne nitens, Lotus corniculatus, Trichosanthes cucumerina, Momordica grosvenori, Epimedium acuminatum, Vancouveria hexandra, Hedyotis verticillata, Uncaria guianensis, Celastrus orbiculatus, Justicia spicigera, Chenopodium murale, Weigela subsessilis, Cinnamomum osmophloeum, Cardamine leucantha, Arabidopsis thaliana, Tagetes erecta, Hibiscus cannabinus, Bryophyllum pinnatum and Geranium thunbergii (17).

b)

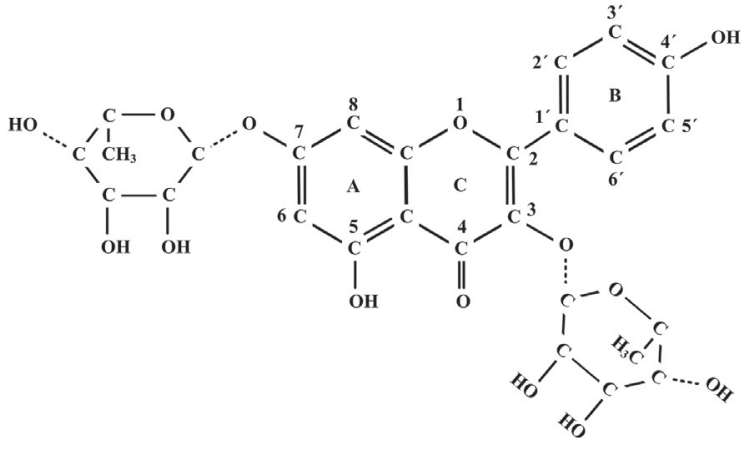

Fig. 3. Structure of: a) kaempferol and b) kaempferitrin 
The extraction of targeted compounds from plants is of utmost importance, since it affects yields, but also purity and quality of the extract. In general, the process consists mainly of three stages: conditioning of sample (homogenisation), initial extraction and pre-concentration/purification (58). The homogenization method, storage and drying conditions will depend on the type of material (leaves, flowers, stems, root or fruit). In order to avoid degradation of components, it is recommended that extraction be made with fresh material stored at freezing temperatures $\left(-80^{\circ} \mathrm{C}\right)$. However, in practice the use of dry samples is preferred due to its easy handling and storage. Furthermore, extraction effectiveness depends on particle size, polarity and solvent $\mathrm{pH}$, temperature and mechanical assistance. Kaempferol is usually extracted using high volume fractions (60-80\%) of methanol or ethanol (58). The main objective of pre-concentration is to obtain or isolate sufficient quantities of target compound. The selection of the pre-concentration method will depend on the available equipment for final analysis, which may require different amounts and target substance purity. Extraction of kaempferol and kaempferitrin is usually carried out by organic solvents (mainly ethanol, methanol and acetone) combined with water; however, it has been suggested that the use of pressurized liquids and supercritical fluids is generally more effective than common procedures due to an increased pressure (57).

Leal et al. (59) used supercritical fluid technology to obtain Ocimum basilicum L. (commonly known as basil) extracts by applying $\mathrm{CO}_{2}(99.8 \%$ ) and bi-distilled water (as a co-solvent) at 1, 10 and $20 \%$ (by mass). A mass of $2.5 \mathrm{~g}$ of sample was used and flow rate was maintained in a range of $5 \cdot 10^{-5}$ to $8 \cdot 10^{-5} \mathrm{~kg} / \mathrm{s}$. The extraction temperature was $303 \mathrm{~K}\left(29.9^{\circ} \mathrm{C}\right)$ and $323 \mathrm{~K}\left(49.9^{\circ} \mathrm{C}\right)$ at pressures of $10,15,20,25$ and $30 \mathrm{MPa}$. The extractions were performed at 15, 30, 45 and $60 \mathrm{~min}$. Results showed a higher yield ( $24 \%$ ) at pressure of $30 \mathrm{MPa}, 20$ $\%$ co-solvent, temperature of $303 \mathrm{~K}$ and extraction time of 60 min. Compounds identified in extracts with $1 \%$ co-solvent were: eugenol, germacrene-D, epi-alpha-cadinol, phytol and neophytadiene. In the extracts obtained with $10 \%$ co-solvent, other types of compounds were identified, such as caffeic, quinic, malic, tartaric and caffeoylquinic (chlorogenic acid) acids, rhamnose, kaempferol, and kaempferol 3-O-glucoside. All identified compounds showed antioxidant activity, however, extracts with 10 and $20 \%$ co-solvent showed a higher antioxidant activity than extracts obtained with $1 \%$ co-solvent at the same extraction temperature (303 K).

Liza et al. (60) determined the optimal conditions for extraction from Strobilanthes crispus leaves by using supercritical $\mathrm{CO}_{2}$ and ethanol (99.5\%) as co-solvent. Independent variables were pressure $(10,15$ and $20 \mathrm{MPa})$, temperature $(40,50$ and $60{ }^{\circ} \mathrm{C}$ ) and dynamic extraction time (40,60 and $\left.80 \mathrm{~min}\right)$. Flow of $\mathrm{CO}_{2}$ and ethanol were maintained constant at 10 and $1 \mathrm{~g} / \mathrm{min}$. A mass of $30 \mathrm{~g}$ of sample (average particle size of 0.5 $\mathrm{mm}$ ) was used, which was mixed with 2.0-mm glass beads. The introduction of some rigid materials in extraction cell allows preserving an adequate $\mathrm{CO}_{2}$ flow rate and maintaining the desired permissiveness of particle during extraction process. Highest yield (5.17\%) was obtained at $20 \mathrm{MPa}, 50^{\circ} \mathrm{C}$ and extraction time $60 \mathrm{~min}$. According to the statistical analysis, pressure had a dominant effect $(\mathrm{k}=1.18)$ on extraction yield, followed by temperature $(k=1.09)$ and, finally, dynamic extraction time $(\mathrm{k}=0.15)$. Value $\mathrm{k}$ represents the range between three average responses for each level of extraction yield. Eight flavonoids were identified in the obtained extract (3.98 $\%$ total flavonoids) under the optimal conditions: (+)-catechin (4.83 mg/g), (-)-epicatechin $(4.55 \mathrm{mg} / \mathrm{g})$, rutin $(8.47 \mathrm{mg} / \mathrm{g})$, myricetin $(4.10 \mathrm{mg} / \mathrm{g})$, luteolin $(12.52 \mathrm{mg} / \mathrm{g})$, apigenin $(3.75$ $\mathrm{mg} / \mathrm{g})$, naringenin $(3.63 \mathrm{mg} / \mathrm{g})$ and kaempferol $(19.45 \mathrm{mg} / \mathrm{g})$ at the highest mass fraction.

Li et al. (61) used the tea seed cake of Camellia sinensis (byproduct of pressing the seeds of green tea during traditional processing to obtain oil) with the aim of developing a rapid and efficient procedure for purification of two glycosides from kaempferol, KG1 (kaempferol-3-O-[2-O- $\beta$-D-galactopyranosyl-6-O-a-L-rhamnopyranosyl]- $\beta$-D-glucopyranoside) and KG2 (kaempferol-3-O-[2-O- $\beta$-D-xylopyranosyl-6-O- $\alpha-$--rhamnopyranosyl]- $\beta$-D-glucopyranoside), using supercritical fluid extraction (SFE). Process optimisation was performed according to response surface methodology (RSM), considering total yield of glycosides as the dependent variable and the following independent variables: extraction time $(30,60,90$, 120 and $150 \mathrm{~min})$, pressure $(15,22.5,30,37.5$ and $45 \mathrm{MPa})$, temperature $\left(40,50,60,70\right.$ and $\left.80^{\circ} \mathrm{C}\right)$ and ethanol volume fraction (as a co-solvent, 50, 60, 70, 80 and $90 \%$ ). Conventional extraction ( $25 \mathrm{~g}$ sample) was performed by using $70 \%$ ethanol reflux and temperature of $70^{\circ} \mathrm{C}$ for $6 \mathrm{~h}$. For the SFE, the same amount of sample was used, which was placed in a 50- $\mathrm{mL}$ stainless steel cell and defatted cotton was placed on the ends. The flow of $\mathrm{CO}_{2}$ and the co-solvent was maintained at 2 and $0.5 \mathrm{~mL} / \mathrm{min}$, respectively. Maximum yield (KG1 $3.5 \mathrm{mg} / \mathrm{g}$ and KG2 $5.42 \mathrm{mg} / \mathrm{g}$ ) was obtained with the longest time (150 min), $30 \mathrm{MPa}$ pressure, $60^{\circ} \mathrm{C}$ temperature and $70 \%$ ethanol. In general, higher yields were correlated with lower pressures (except for longer extraction time, when yield did not depend on the pressure) and with the increase in temperature, probably due to higher speed of mass transfer. Higher yields were obtained at 60 and $70 \%$ ethanol. According to RSM, the optimal conditions were: extraction time $150 \mathrm{~min}$, pressure 20 $\mathrm{MPa}$, temperature $80^{\circ} \mathrm{C}$ and $60 \%$ ethanol, under which total yield was (11.4 \pm 0.4$) \mathrm{mg} / \mathrm{g}$. Regarding conventional method, the yield was $(11.6 \pm 0.2) \mathrm{mg} / \mathrm{g}$, which was not significantly different from that obtained by SFE. However, conventional method required $500 \mathrm{~mL}$ of ethanol and extraction time of $6 \mathrm{~h}$, while for SFE the amount of ethanol and extraction time were lower ( $75 \mathrm{~mL}$ and $2.5 \mathrm{~h}$ ).

As stated above, one of the main disadvantages of supercritical $\mathrm{CO}_{2}$ is its low polarity (it behaves like a lipophilic solvent), which results in a minimal extraction of polar compounds, mainly phenols, flavonoids and terpenoids. Flavonoids that have in their structure the most unsubstituted hydroxyl groups or molecules of a sugar are considered polar 
compounds and are moderately soluble in polar solvents (ethanol, methanol, butanol, acetone and water). Otherwise, less polar aglycones (flavonoid without sugar) such as isoflavones and flavanones are more soluble in solvents such as ether and chloroform (62). However, it has been reported (63$65)$ that some phenolic and flavonoid compounds are actually soluble in supercritical $\mathrm{CO}_{2}$ when pressures are high (above $20 \mathrm{MPa}$ ) due to fluid density increases at increasing pressure. In this regard, Sanjaya et al. (66) conducted a study in which they used supercritical $\mathrm{CO}_{2}$ for extraction of some phenolic compounds and flavonoids from Myrmecodia pendans. The static extractions were carried out at different pressures (9.0, $10.5,12.0,13.5,15.0,16.5,18.0,19.5,21.0$ and $22.5 \mathrm{MPa})$ and temperatures (313.15 (40), 323.15 (50), 333.15 (60) and 343.15 $\left.\mathrm{K}\left(70{ }^{\circ} \mathrm{C}\right)\right)$, for 6 to $7 \mathrm{~h}$. The sample $(10 \mathrm{~g})$ was placed in a cell (40 MPa maximum pressure) packed with glass beads and $\mathrm{CO}_{2}$ was charged to the system by a reciprocating pump with a $10 \mathrm{~mL} / \mathrm{min}$ constant flow. Moreover, extractions by reflux (Soxhlet extraction) were carried out with ethanol (96\%) at atmospheric pressure and temperature of $343.15 \mathrm{~K}\left(70^{\circ} \mathrm{C}\right)$, using the same amount of sample. Yields, antioxidant capacity of extracts, solubility of total polyphenols (in mg of gallic acid equivalents (GAE) per $\mathrm{L}$ of $\mathrm{CO}_{2}$ ) and total flavonoids (in mg of quercetin equivalents $(\mathrm{QE})$ per $\mathrm{L}$ of $\mathrm{CO}_{2}$ ) were determined in accordance with density equations of Chrastil (67) and Del Valle and Aguilera (68). According to the authors (66), extractions with supercritical $\mathrm{CO}_{2}$ were performed in static mode, because it is simpler and allows extraction with less fluid than the dynamic extraction. Nine compounds were identified in extracts obtained with Soxhlet extraction: gallic acid, (+)-catechin, caffeic acid, $p$-coumaric acid, ferulic acid, rutin, quercetin, luteolin and kaempferol. The compounds identified in the supercritical $\mathrm{CO}_{2}$ extract at $22.5 \mathrm{MPa}$, varied according to the extraction temperature. At $313.15 \mathrm{~K}$ gallic acid, caffeic acid, $p$-coumaric acid, quercetin and kaempferol were identified, at $323.15 \mathrm{~K}$ all compounds except ferulic acid and rutin, while at 333.15 and $343.15 \mathrm{~K}$ all but rutin were found. Total content of polyphenols and flavonoids was higher in extracts obtained with Soxhlet extraction ((28.07 \pm 1.28$)$ mg GAE/g dry sample and (16.44 \pm 0.58$) \mathrm{mg} Q E / g$ dry sample) than with supercritical $\mathrm{CO}_{2}$ at $22.5 \mathrm{MPa}$ and $343.15 \mathrm{~K}$ ((16.41 \pm 1.08$) \mathrm{mg} \mathrm{GAE} / \mathrm{g}$ dry sample and $(2.96 \pm 0.15) \mathrm{mg} \mathrm{QE} / \mathrm{g}$ dry sample). However, the purity of phenolic compounds in extracts obtained with supercritical $\mathrm{CO}_{2}$ (34.3 to $48.7 \%$ ) was higher than of extracts obtained with Soxhlet extraction (18.3\%). This indicates that supercritical $\mathrm{CO}_{2}$ is a more selective solvent than liquid ethanol. The mass fractions of gallic, caffeic and $p$-coumaric acids, quercetin and kaempferol increased with increasing extraction temperature (22.5 MPa constant pressure). Polyphenolic and flavonoid compound solubility increased significantly with increasing pressure and temperature (this was observed in the pressure range of 12 to $22.5 \mathrm{MPa}$ ). In this pressure range, the authors conclude that temperature effect on the increase of solute solubility seems to be more significant than pressure. With regard to antioxidant capacity (DPPH method), extracts showed an inhibition range of 37 to $76 \%$ using $10 \mathrm{mg} / \mathrm{mL}$ of extract. Extract obtained with supercritical $\mathrm{CO}_{2}$ at $22.5 \mathrm{MPa}$ and $343.15 \mathrm{~K}$ showed the highest inhibition $((76.17 \pm 0.27) \%)$, while the extract obtained with Soxhlet extraction had the lowest inhibition ((36.64 \pm 0.15$) \%)$. Moreover, the $\mathrm{IC}_{50}$ of the extract with the highest inhibition was $(3.62 \pm 0.12) \mathrm{mg} / \mathrm{mL}$. The above shows that purer extracts are achieved with supercritical $\mathrm{CO}_{2}$ than with the Soxhlet conventional extraction.

Wang et al. (69) used supercritical $\mathrm{CO}_{2}$ to obtain bioactive compounds from Ampelopsis grossedentata stems. Four factors and three levels were used to perform the extractions: pressure $(15,20$ and $25 \mathrm{MPa})$, temperature $\left(40,50\right.$ and $\left.60^{\circ} \mathrm{C}\right)$, dynamic extraction time (30,50 and $70 \mathrm{~min})$ and methanol/ ethanol ratio (1:3, 1:1 and 3:1, by volume). A mass of $20 \mathrm{~g}$ of sample was used, and $\mathrm{CO}_{2}$ and co-solvent flow were maintained at 2 and $0.5 \mathrm{~mL} / \mathrm{min}$, respectively. The amount of flavonoids and total phenols was determined, as well as the antioxidant capacity of the extracts and the identification of the main flavonoids. The highest content of total flavonoids ((4.67 \pm 0.36$) \mathrm{mg}$ rutin equivalents per $\mathrm{g}$ dry sample) and total phenols ((2.49 \pm 0.10$) \mathrm{mg}$ GAE per g dry sample) was obtained at $25 \mathrm{MPa}, 40^{\circ} \mathrm{C}$ and $50 \mathrm{~min}$, with a methanol/ethanol ratio 1:3 for total flavonoids and 1:1 for total phenols. Antioxidant capacity (DPPH method) of extracts had a range from 40.69 to $95.87 \%$. Extract obtained at $25 \mathrm{MPa}, 40{ }^{\circ} \mathrm{C}, 50 \mathrm{~min}$ and a methanol/ethanol ratio 1:1 showed the highest inhibition, and the highest content ( $(2.55 \pm 0.2) \mathrm{mg} / \mathrm{g}$ dry sample) of the main flavonoids identified in the different extracts (dihydromyricetin (ampelopsin), vitexin-2"-O-rhamnoside, vitexin, rutin, quercetin-3-galactoside, myricetin, luteolin, quercetin, apigenin and kaempferol), with ampelopsin as the major compound with $99.4 \%$ total content. In that work it was observed that supercritical $\mathrm{CO}_{2}$ density is a decisive factor in the extraction, since, at higher pressures, the yield is higher, while with increasing temperature, the yield decreases. This is due to the fact that supercritical $\mathrm{CO}_{2}$ density is greater as the pressure increases, and it decreases as the temperature increases. Authors conclude that the decrease of supercritical $\mathrm{CO}_{2}$ density influences the extraction more than the increase of vapour pressure of the solute.

\section{Applications in food processing}

In the last few decades, dietary habits of consumers have been changing, which has caused greater demands on the supply of products that, in addition to providing nutrients, offer health benefits. On the current market, these foods are known as 'functional foods'. These can be defined as foods that contain significant levels of biologically active components (mainly vitamins E and C, polyphenolic acids, flavonoids and anthocyanins) that provide specific benefits for health beyond their traditional nutrients (70-72). Supercritical fluid (SCF) technology is increasingly applied in different areas (mainly food and pharmaceutical), because many natural compounds, such as vitamins, aromas, pigments or essential oils, are very soluble 
in supercritical fluids (73). One of the most widely studied applications of this technology is obtaining bioactive compounds from plants, fruits, legumes and aromatic seeds, with the purpose of using them as functional ingredients in foods, mainly as natural antioxidants $(74,75)$. Lipid oxidation is one of the main problems of processed foods. Although initially synthetic antioxidants were used in order to avoid lipid oxidation, new trends are the use of natural sources that are applied to different foods in order to avoid their degradation, increase their shelf life, improve their sensory properties and provide bioactive compounds to improve consumer health. Some foodstuffs containing extracts of vegetable sources include: red meat, sausages, pork nuggets, hamburgers, pies with pork or chicken meat, margarine, beef meatballs, white shrimp, vegetable oil, potatoes and apples, among others (76). Another relevant aspect is active packaging, with the focus on bio-based functional packaging materials incorporating natural active compounds and ingredients. Phenolic compounds can be incorporated into polymers or into carriers that may be extruded or coated into packaging materials (76). Active packaging can be defined as a mode of packaging in which the package, the product, and the environment interact, extending shelf life and improving safety or sensory properties, while maintaining food product quality $(76,77)$.

It has been estimated that human intake of flavonoids is 2 to $34 \mathrm{mg} /$ day, with an average of $23 \mathrm{mg} /$ day, of which most are flavonols. From this intake, quercetin represents $70 \%$, followed by kaempferol with $17 \%$, myricetin with $6 \%$, luteolin with $4 \%$, and apigenin with $3 \%(78,79)$. In the specific case of kaempferol, an average intake of $10 \mathrm{mg} /$ day has been estimated (80). The main food sources of this compound are: black tea, broccoli, onions, apples, strawberries, black pepper, green tea and alcoholic beverages such as wine. According to Martínez-Flórez et al. (81), consumption of flavonols is higher than other antioxidants in the diet, such as $\beta$-carotene $(2-3$ $\mathrm{mg} /$ day), vitamin $\mathrm{E}$ (7-10 $\mathrm{mg} / \mathrm{day}$ ) and the equivalent of one third of vitamin C consumption (70-100 mg/day). Therefore, consumption of flavonols (mainly quercetin and kaempferol) in human diet is of great significance due to functional properties of these compounds.

In accordance with the above, supercritical fluid technology for obtaining bioactive compounds from plant sources and even from byproducts generated by food industry is projected as a feasible option for development of functional foods and beverages, food supplements (capsules, tablets), as well as drugs. An example of the foregoing is rutin (quercetin-3- $\beta$-D-rutinoside), which is so far the only flavonoid in medicinal products in Mexico (55). Food supplements from flavonoids (mainly quercetin) are produced in combination with other substances such as vitamins (mainly $C$ and $E$ ) some enzymes (bromelain) that help improve flavonoid absorption (79). In the specific case of vitamins $C$ and $E$, there is a synergistic effect with quercetin, since vitamin $C$ reduces quercetin oxidation, whereas quercetin prevents the oxidation of vitamin $\mathrm{E}$ (55).
One of the main problems of bioactive compounds is their stability under environmental conditions during their storage (temperature, presence of oxygen and light, humidity, etc.). In this regard, encapsulation technologies have been used to prevent degradation of these compounds, the most frequently used are spray drying and lyophilisation. The first usually uses high temperatures (above $100^{\circ} \mathrm{C}$ ), while the second is time consuming, resulting in high production costs. Microencapsulation using supercritical $\mathrm{CO}_{2}$ is an alternative, since it has advantages over the traditional methods mentioned above, mainly the use of temperatures close to the environmental, the possibility of continuous modulation, reduced energy consumption, oxidation reaction prevention and high product quality by avoiding polluting organic solvents (82). In the specific case of flavonols, with this microencapsulation technology, in addition to preventing their degradation, their solubility can be increased and bioavailability improved. The advantages of the SCF technology and its ability to adapt by varying pressure and temperature (and even the use of co-solvents) in the extraction processes resulted in the development of different precipitation techniques that can process a wide variety of materials, producing various particle sizes and controlled morphologies. These advantages are also applicable for encapsulation and co-precipitation by SCF and, in turn, can take the advantage of supercritical fluid capacity to modify the properties of encapsulating polymer material (plasticization, swelling, fusion temperature reduction, etc.), as well as the interactions between the encapsulant and active substance, a capacity that can enable modifying and controlling the way in which active substance is incorporated into the encapsulant (83). De Paz et al. (84) prepared formulations with quercetin and different encapsulants (Pluronic L64 ${ }^{\circledR}$, modified starch and soy lecithin) with the aim of providing greater solubility and stability in aqueous media. Supercritical drying process was carried out at 40 ${ }^{\circ} \mathrm{C}$ and $12 \mathrm{MPa}$, with a constant flow of the solution and $\mathrm{CO}_{2}$ of $0.2 \mathrm{~mL} / \mathrm{min}$ and $13 \mathrm{~kg} / \mathrm{h}$, respectively. The best quercetin encapsulation efficiency was obtained with lecithin (above $90 \%$ ), with an average particle size of $10 \mu \mathrm{m}$. Similar results were obtained by Lévai et al. (85), by producing encapsulated quercetin microparticles from an oil-in-water emulsion, using supercritical $\mathrm{CO}_{2}\left(11 \mathrm{MPa}\right.$ and $\left.40{ }^{\circ} \mathrm{C}\right)$ and two types of surfactants, Pluronic L64 ${ }^{\circledR}$ and soy lecithin. Better results were obtained with soy lecithin, with an average particle size of $100 \mathrm{~nm}(0.1 \mu \mathrm{m})$ and encapsulation efficiency $70 \%$. Furthermore, quercetin antioxidant activity was improved with encapsulation.

Deniz et al. (82) investigated the extraction conditions with supercritical $\mathrm{CO}_{2}$ to obtain phycocyanin from microalga Spirulina (Arthrospira) platensis. This compound is the main phycobiliprotein in S. platensis of natural blue colour that is used as food colouring for chewing gums, sorbets, soft drinks, candies and cosmetics. Phycocyanin has antioxidant, anticarcinogenic, anti-inflammatory, hepatoprotective, neuroprotective and cardioprotective properties (72). 
The sample was conditioned to a particle size between 0.1 and $0.3 \mathrm{~mm}$. Extraction was performed at different temperatures $\left(30,50,60\right.$ and $\left.80^{\circ} \mathrm{C}\right)$, pressures $(15,25$ and $35 \mathrm{MPa})$, extraction times $(45,60,90$ and $120 \mathrm{~min})$ and ethanol as co-solvent $(0,10$ and $15 \%)$. Sample mass was $30 \mathrm{~g}$ and flow of $\mathrm{CO}_{2}$ and mixtures with ethanol was $10 \mathrm{~g} / \mathrm{min}$. Moreover, conventional extractions were carried out in order to compare the methods. Dependent variable was phycocyanin concentration in extracts, and the effect of cytotoxicity against lung cancer cell line A549 at different extract concentrations (0$100 \mu \mathrm{g} / \mathrm{mL}$ ). Optimal parameters were: $25 \mathrm{MPa}, 60^{\circ} \mathrm{C}, 10 \%$ ethanol as a co-solvent and extraction time of $45 \mathrm{~min}$. Under these conditions, phycocyanin content was $90.74 \%$ with purity $75.12 \%$. The extract obtained with supercritical $\mathrm{CO}_{2}$ showed greater cytotoxicity against the lung cancer cell line A549 than with conventional extraction. This is confirmed by $\mathrm{IC}_{50}$ value, which was 26.82 and $36.94 \mu \mathrm{g} / \mathrm{mL}$ for the extracts obtained with supercritical $\mathrm{CO}_{2}$ and conventional extraction, respectively. In general, results gave important information about phycocyanin extraction with supercritical fluids as an alternative to conventional methods and the possibility of including this compound in daily diet for preventive purposes against lung cancer. In this regard, Yan et al. (86) developed a method for obtaining phycocyanin microcapsules using alginate and chitosan in order to improve their stability and control the compound release, representing a feasible option for development of functional foods.

Nanotechnology is an area that is gaining major importance, mainly in agri-food industry and medicine. One of the main applications of this technology is the development of delivery systems such as emulsions, biopolymer matrices, simple solutions and association colloids, to maintain active compounds at suitable levels for long periods of time. Nanoparticles have better encapsulation and release properties than traditional encapsulation systems, thus substances with functional properties can be encapsulated and released in response to certain specific environments (87). In medicine, it has been used for development of efficient systems of drug delivery against cancer. Luo et al. (88) developed nanoparticles with kaempferol and evaluated their efficacy in inhibiting malignant and normal ovarian cell viability. Different polymers for nanoparticle preparation (with and without kaempferol) were used, PLGA (polylactic-co-glycolic acid), Pluronic ${ }^{\circledR}$ P123 (surfactant), chitosan, PLGA-PEI (polyethyleneimine) in a 10:1 ratio and PAMAM (polyamidoamine). To develop kaempferol nanoparticles, 250- $\mu \mathrm{L}$ kaempferol solution (50 mg/ $\mathrm{mL}$ in $0.2 \mathrm{M}$ dimethylsulfoxide) was mixed with $1 \mathrm{~mL}$ polymer solution. Nanoparticles were evaluated according to their average particle size and their inhibitory effect on ovarian cancer cell lines (A2780/CP70 and OVCAR-3). Their size ranged from 160 to $250 \mathrm{~nm}$, particles made with Pluronic ${ }^{\circledR}$ P123 had the smallest size $((160 \pm 30) \mathrm{nm})$, while the largest ones were those made with PAMAM $((250 \pm 70) \mathrm{nm})$. Kaempferol nanoparticles made with polymers, PLGA-PEl, chitosan and PAMAM did not reduce significantly cell viability of ovarian cancer cells A2780/CP70. Rather, those made with Pluronic ${ }^{\circledast}$ P123 and PLGA significantly reduced cell viability, both of A2780/CP70 and OVCAR-3, in comparison with kaempferol alone (in phosphate-buffered saline). Results obtained in that work show that kaempferol nanoparticle formulations with Pluronic ${ }^{\oplus} \mathrm{P} 123$ and PLGA polymers could be an alternative for cancer treatment, due to their improved capacity to reduce cancer cell viability, as well as a non-significant reduction of the viability of normal ovarian cells.

\section{CONCLUSIONS}

The above-mentioned evidence of the therapeutic use and as a possible agent for the prevention and treatment of some diseases of kaempferol and some of its glycosides shows that extracts from plant sources obtained by supercritical fluid technology constitute an important alternative in the development of functional foods and nutraceuticals. As already mentioned in this review, extracts obtained by supercritical fluid technology have a higher purity, which gives them better functional properties. Therefore, this is an area of opportunity of great interest in new concepts of food packaging, the active packaging, which enables further prolongation of food shelf life. Likewise, antioxidant capacity of kaempferol and its glycosides obtained by extraction with supercritical fluids against the effects of different types of cancer, as well as harmful effects of hyperglycaemia, should be considered as an alternative for prevention and treatment of these conditions.

\section{ACKNOWLEDGEMENTS}

S. Cid-Ortega thanks to National Council of Science and Technology (CONACyT) and Technological National of Mexico/Technological Institute of Veracruz for the scholarship granted to complete his postdoctoral residence.

\section{REFERENCES}

1. Andrade-Cetto A, Heinrich M. Mexican plant with hipoglycaemic effect used in the treatment of diabetes. J Ethnopharmacol. 2005;99(3):325-48.

https://doi.org/10.1016/j.jep.2005.04.019

2. Alonso-Castro AJ, Maldonado-Miranda JJ, Zarate-Martinez $A$, del Rosario Jacobo-Salcedo M, Fernández-Galicia C, Figueroa-Zuñiga LA, et al. Medicinal plants used in the Huasteca Potosina, México. J Ethnopharmacol. 2012;143(1): 292-8.

https://doi.org/10.1016/j.jep.2012.06.035

3. Azwanida NN. A review on the extraction methods use in medicinal plants, principle, strength and limitation. Med Aromat Plants. 2015;4(3):1000196.

https://doi.org/10.4172/2167-0412.1000196

4. Biruete Guzmán A, Juárez Hernández E, Sieiro Ortega $E$, Romero Viruegas R, Silencio Barrita JL. Nutraceutics. What 
is convenient to know. Rev Mex Pediatr. 2009;76(3):136-45 (in Spanish).

5. Mahadevan N, Shivali, Kamboj P. Hibiscus sabdariffa Linn. An overview. Nat Prod Rad. 2009;8:77-83.

6. Carvajal-Zarrabal O, Barradas-Dermitz DM, Orta-Flores Z, Hayward-Jones PM, Nolasco-Hipólito C, Aguilar-Uscanga MG, et al. Hibiscus sabdariffa L., roselle calyx, from ethnobotany to pharmacology. J Exp Pharmacol. 2012;4:25-39. https://doi.org/10.2147/JEP.S27974

7. Sovová, H, Stateva RP. Supercritical fluid extraction from vegetable materials. Rev Chem Eng. 2011;27(3-4):79-156. https://doi.org/10.1515/REVCE.2011.002

8. Euler KL, Alam M. Isolation of kaempferitrin from Justicia spicigera. J Nat Prod. 1982;45(2):220-1. https://doi.org/10.1021/np50020a020

9. Imperato F. Flavonol glycosides from Pteridium aquilinum. Phytochemistry. 1995;40(6):1801-2. https://doi.org/10.1016/0031-9422(95)00593-V

10. Xiao ZP, Wu HK, Wu T, Shi H, Hang B, Aisa HA. Kaempferol and quercetin flavonoids from Rosa rugosa. Chem Nat Compd. 2006;42(6):736-7. https://doi.org/10.1007/s10600-006-0267-3

11. Singh R, Singh B, Singh S, Kumar N, Kumar S, Arora S. Anti-free radical activities of kaempferol isolated from Acacia nilotica (L.) Willd. Ex. Del. Toxicol In Vitro. 2008;22(8):1965-70. https://doi.org/10.1016/j.tiv.2008.08.007

12. Sultana B, Anwar F. Flavonols (kaempeferol, quercetin, myricetin) contents of selected fruits, vegetables and medicinal plants. Food Chem. 2008;108(3):879-84. https://doi.org/10.1016/j.foodchem.2007.11.053

13. Aguirre-Hernández E, González-Trujano ME, Martínez AL, Moreno J, Kite G, Terrazas T, Soto-Hernández E. HPLC/MS analysis and anxiolytic-like effect of quercetin and kaempferol flavonoids from Tilia americana var. mexicana. J Ethnopharmacol. 2010;127(1):91-7. https://doi.org/10.1016/j.jep.2009.09.044

14. Dong JZ, Gao WS, Lu D, Wang Y. Simultaneous extraction and analysis of four polyphenols from leaves of Lycium barbarum L. J Food Biochem. 2011;35(3):914-31. https://doi.org/10.1111/j.1745-4514.2010.00429.x

15. Liu L, Liu RL, Zhang J, Zhang ZQ. Study on the PEG-based microwave-assisted extraction of flavonoid compounds from persimmon leaves. J Sep Sci. 2012;35(23):3412-20. https://doi.org/10.1002/jssc.201200495

16. Mercader-Ros MT, Lucas-Abellán C, Fortea MI, Serrano-Martínez A, Gabaldón JA, Núnez-Delicado E. Biological activities of kaempferol: Effect of cyclodextrins complexation on the properties of kaempferol. In: Villers G, Fougere Y, editors. Kaempferol: Chemistry, natural occurrences and health benefits. New York, NY, USA: Nova Science Publishers, Inc.; 2013. pp. 1-31.
17. Barreto-Silva FRM, Zanatta L, Silva-Frederico MJ, Pizzolatti MG, De Campos AM. Kaempferol and kaempferitrin: Nutraceutical compounds contribute to glucose homeostasis by acting at multiple biological sites. In: Villers $G$, Fougere $Y$, editors. Kaempferol. Chemistry, natural occurrences and health benefits. New York, NY, USA: Nova Science Publishers, Inc.; 2013. pp. 33-62.

18. Da Silva D, Marques Casanova L, Calestino Marcondes M, Espindola-Netto JM, Pereira Paixão L, Oliveira De Melo G, et al. Antidiabetic activity of Sedum dendroideum: Metabolic enzymes as putative targets for the bioactive flavonoid kaempferitrin. IUBMB Life. 2014;66(5):361-70.

https://doi.org/10.1002/iub.1270

19. Alonso-Castro AJ, Ortiz-Sánchez E, García-Regalado A, Ruiz G, Núñez-Martínez JM, González-Sánchez I, et al. Kaempferitrin induces apoptosis via intrinsic pathway in HeLa cells and exerts antitumor effects. J Ethnopharmacol. 2013;145(2):476-89.

https://doi.org/10.1016/j.jep.2012.11.016

20. Perrut M. Supercritical fluid applications: industrial developments and economic issues. Ind Eng Chem Res. 2000; 39(12):4531-5.

https://doi.org/10.1021/ie000211c

21. Beckman EJ. Supercritical and near-critical $\mathrm{CO}_{2}$ in green chemical synthesis and processing. J Supercrit Fluids. 2004;28(2-3):121-91.

https://doi.org/10.1016/S0896-8446(03)00029-9

22. Díaz-Reinoso B, Moure A, Domínguez H, Parajó JC. Supercritical $\mathrm{CO}_{2}$ extraction and purification of compounds with antioxidant activity. J Agric Food Chem. 2006;54(7):244169.

https://doi.org/10.1021/jf052858j

23. Luque de Castro MD, Valcárcel M, Tena MT, editors. Supercritical fluid extraction in an analytical process. Barcelona, España: Reverté SA.; 1993 (in Spanish).

24. Ordóñez AF, Rojas NY, Parada F, Rodríguez I. Comparative study of caffeine extraction with supercritical $\mathrm{CO}_{2}$ and ethyl acetate. Rev Ing. 2006;24:34-42. (in Spanish).

25. Yang C, Xu YR, Yao WX. Extraction of pharmaceutical components from Ginkgo biloba leaves using supercritical carbon dioxide. J Agric Food Chem. 2002;50(4):846-9. https://doi.org/10.1021/jf010945f

26. Chafer A, Fornari T, Berna A, Stateva RP. Solubility of quercetin in supercritical $\mathrm{CO}_{2}+$ ethanol as a modifier: Mea- surements and thermodynamic modelling. J Supercrit Fluids. 2004;32(1-3):89-96.

https://doi.org/10.1016/j.supflu.2004.02.005

27. Ayora Talavera TR, Gastélum Martínez E. Phenols and polyphenols. In: Espinosa Andrews H, García Marquez E, Gastélum Martínez E, editors. Bioactive compounds and extraction techniques. Zapopan, Jalisco, México: CIATEJ, A.C.; 2016. pp. 59-72 (in Spanish). 
28. Grigore A. Plant phenolic compounds as immunomodulatory agents. In: Soto-Hernandez M, Palma-Tenango M, Garcia-Mateos MR, editors. Phenolic compounds - Biological activity. London, UK: IntechOpen; 2017. pp. 75-98. https://doi.org/10.5772/66112

29. Shahidi F, Ambigaipalan P. Phenolics and polyphenolics in foods, beverages and spices: Antioxidant activity and health effects - A review. J Funct Foods. 2015;18(Pt B):82097.

\section{https://doi.org/10.1016/j.jff.2015.06.018}

30. Cui Y, Morgenstern H, Greenland S, Tashkin DP, Mao JT, Cai $\mathrm{L}$, et al. Dietary flavonoid intake and lung cancer - A population-based case-control study. Cancer. 2008;112(10):2241-8. https://doi.org/10.1002/cncr.23398

31. Calderon-Montano JM, Burgos-Morón E, Pérez-Guerrero C, López-Lázaro M. A review on the dietary flavonoid kaempferol. Mini Rev Med Chem. 2011;11(4):298-344. https://doi.org/10.2174/138955711795305335

32. Basli A, Belkacem N, Amrani I. Health benefits of phenolic compounds against cancers. In: Soto-Hernandez M, Palma-Tenango M, Garcia-Mateos MR, editors. Phenolic compounds - Biological activity. London, UK: IntechOpen; 2017. pp. 193-210.

https://doi.org/10.5772/67232

33. Cancer. Geneve, Switzerland: World Health Organization (WHO); 2018. Available from: http://www.who.int/mediacentre/factsheets/fs297/en/.

34. Chen AY, Chen YC. A review of the dietary flavonoid, kaempferol on human health and cancer chemoprevention. Food Chem. 2013;138(4):2099-107.

https://doi.org/10.1016/j.foodchem.2012.11.139

35. Nöthlings U, Murphy SP, Wilkens LR, Henderson BE, Kolonel LN. Flavonols and pancreatic cancer risk: The multiethnic cohort study. Am J Epidemiol. 2007;166(8):924-31.

https://doi.org/10.1093/aje/kwm172

36. Alonso-Castro AJ, Ortiz-Sánchez E, Domínguez F, Arana-Argáez V, del Carmen Juárez-Vázquez M, Chávez M, et al. Antitumor and immunomodulatory effects of Justicia spicigera Schltdl (Acanthaceae). J Ethnopharmacol. 2012;141(3):88894.

https://doi.org/10.1016/j.jep.2012.03.036

37. Fernández-Pomares $C$, Juárez-Aguilar E, Domínguez-Ortiz MÁ, Gallegos-Estudillo J, Herrera-Covarrubias D, Sánchez-Medina A, et al. Hydroalcoholic extract of the widely used Mexican plant Justicia spicigera Schltdl. exerts a cytostatic effect on LNCaP prostate cancer cells. J Herb Med. 2017;12:66-72.

https://doi.org/10.1016/j.hermed.2017.09.003

38. Marfe G, Tafani M, Indelicato M, Sinibaldi-Salimei $P$, Reali V, Pucci B, et al. Kaempferol induces apoptosis in two different cell lines via Akt inactivation, Bax and SIRT3 activation, and mitochondrial dysfunction. J Cell Biochem.
2009;106(4):643-50

https://doi.org/10.1002/jcb.22044

39. Ackland, ML, Van de Waarsenburg S, Jones R. Synergistic antiproliferativeaction of the flavonols quercetin and kaempferol in cultured human cancer cell lines. In vivo. 2005;19(1):69-76.

40. Luo H, Rankin GO, Li Z, DePriest L, Chen YC. Kaempferol induces apoptosis in ovarian cancer cells through activating p53 in the intrinsic pathway. Food Chem. 2011;128(2):513-9. https://doi.org/10.1016/j.foodchem.2011.03.073

41. Cascales Angosto M. Molecular basis of apoptosis. Anal Real Acad Nal Farm. 2003;69(1):36-64 (in Spanish).

42. Choi EJ, Ahn WS. Kaempferol induced the apoptosis via cell cycle arrest in human breast cancer MDA-MB-453 cells. Nutr Res Pract. 2008;2(4):322-5.

https://doi.org/10.4162/nrp.2008.2.4.322

43. Pinedo A, García-Moraga C, Lugo-Sepulveda E, EncisoMartínez Y. Chronic degenerative diseases in patients who go to the medical specialties unit. RelbCi. 2017;4(5):92-7 (in Spanish).

44. Diabetes. Geneva, Switzerland: World Health Organization (WHO); 2017. Available from: http://www.who.int/mediacentre/factsheets/fs312/en/.

45. Esquivel-Gutiérrez ER, Noriega-Cisneros R, Bello-González MA, Saavedra-Molina A, Salgado-Garciglia R. Plants with antidiabetic and antihypertensive properties used in traditional Mexican medicine. Biológicas. 2012;14(1):45-52 (in Spanish).

46. Bobe G, Young M, Lanza E, Cross AJ, Colburn NH. Chemoprotective effects of kaempferol in colorectal tumorigenesis. In: Villers G, Fougere Y, editors. Kaempferol. Chemistry, natural occurrences and health benefits. New York, NY, USA: Nova Science Publishers, Inc.; 2013. pp. 149-70.

47. Mohan S, Nandhakumar L. Role of various flavonoids: Hypotheses on novel approach to treat diabetes. JMHI. 2014; 8(1):1-6. https://doi.org/10.1016/j.jmhi.2013.06.001

48. de Sousa E, Zanatta L, Seifriz I, Creczynski-Pasa TB, Pizzolatti MG, Szpoganicz B, Barreto Silva RM. Hypoglycemic effect and antioxidant potential of kaempferol-3,7-O-(a)-dirhamnoside from Bauhinia forficata leaves. J Nat Prod. 2004;67(5): 829-32.

https://doi.org/10.1021/np030513u

49. Tzeng CW, Yen FL, Wu TH, Ko HH, Lee CW, Tzeng WS, Lin CC. Enhancement of dissolution and antioxidant activity of kaempferol using a nanoparticle engineering process. J Agric Food Chem. 2011;59(9):5073-80. https://doi.org/10.1021/jf200354y

50. Lévai G, Martín Á, de Paz E, Rodríguez-Rojo S, Cocero MJ. Production of stabilized quercetin aqueous suspensions by supercritical fluid extraction of emulsions. J Supercrit Fluids. 2015;100:34-45.

https://doi.org/10.1016/j.supflu.2015.02.019 
51. Ortiz-Andrade R, Cabañas-Wuan A, Arana-Argáez VE, Alonso-Castro AJ, Zapata-Bustos R, Salazar-Olivo LA, et al. Antidiabetic effects of Justicia spicigera Schltdl (Acanthaceae). J Ethnopharmacol. 2012;143(2):455-62.

https://doi.org/10.1016/j.jep.2012.06.043

52. Gómez-Zorita S, Urdampilleta A. GLUT4: Effects of physical activity and nutrition on glucose uptake mechanisms and their application in type 2 diabetes. Av Diabetol. 2012;28(1): 19-26 (in Spanish).

https://doi.org/10.1016/j.avdiab.2012.02.003

53. Prasad CV, Mohan SS, Banerji A, Gopalakrishnapillai A. Kaempferitrin inhibits GLUT4 translocation and glucose uptake in 3T3-L1 adipocytes. Biochem Biophys Res Commun. 2009;380(1):39-43.

https://doi.org/10.1016/j.bbrc.2009.01.008

54. Sarian MN, Ahmed QU, So'ad SZM, Alhassan AM, Murugesu $S$, Perumal V, et al. Antioxidant and antidiabetic effects of flavonoids: A structure-activity relationship based study. BioMed Res Int. 2017;2017:Article ID 8386065.

https://doi.org/10.1155/2017/8386065

55. Escamilla-Jiménez Cl, Cuevas-Martínez EY, Guevara-Fonseca J. Flavonoids and their antioxidant actions. Rev Fac Med UNAM. 2009;52(2):73-5 (in Spanish).

56. Cassani J, Dorantes-Barrón AM, Novales LM, Real GA, Estrada-Reyes R. Anti-depressant-like effect of kaempferitrin isolated from Justicia spicigera Schltdl (Acanthaceae) in two behavior models in mice: Evidence for the involvement of the serotonergic system. Molecules. 2014;19(12):21442-61. https://doi.org/10.3390/molecules191221442

57. Hosseinzadeh $\mathrm{H}$, Motamedshariaty V, Hadizadeh F. Antidepressant effect of kaempferol, a constituent of saffron (Crocus sativus) petal, in mice and rats. Pharmacology Online. 2007;2:367-70.

58. Biba O, Strnad M, Gruz J. Analytical approaches for kaempferol determination. In: Villers G, Fougere Y, editors. Kaempferol. Chemistry, natural occurrences and health benefits. New York, NY, USA: Nova Science Publishers, Inc.; 2013. pp. 97-147.

59. Leal PF, Maia NB, Carmello QA, Catharino RR, Eberlin MN, Meireles MAA. Sweet basil (Ocimum basilicum) extracts obtained by supercritical fluid extraction (SFE): Global yields, chemical composition, antioxidant activity, and estimation of the cost of manufacturing. Food Bioprocess Tech. 2008;1:326.

https://doi.org/10.1007/s11947-007-0030-1

60. Liza MS, Rahman RA, Mandana B, Jinap S, Rahmat A, Zaidul ISM, Hamid A. Supercritical carbon dioxide extraction of bioactive flavonoid from Strobilanthes crispus (Pecah Kaca). Food Bioprod Process. 2010;88(2-3):319-26.

https://doi.org/10.1016/j.fbp.2009.02.001

61. Li B, Xu Y, Jin YX, Wu YY, Tu YY. Response surface optimization of supercritical fluid extraction of kaempferol glycosides from tea seed cake. Ind Crops Prod. 2010;32(2):123-8.

https://doi.org/10.1016/j.indcrop.2010.04.002

62. Cartaya O, Reynaldo I. Flavonoids: Chemical characteristics and applications. Cultivos Tropicales. 2001;22(2):5-14 (in Spanish).

63. Choi ES, Noh MJ, Yoo KP. Solubilities of o-, m- and p-coumaric acid isomers in carbon dioxide at 308.15-323.15 Kand 8.5-25 MPa. J Chem Eng Data. 1998;43(1):6-8.

https://doi.org/10.1021/je970130w

64. Murga R, Sanz MT, Beltrán S, Cabezas JL. Solubility of some phenolic compounds contained in grape seeds, in supercritical carbon dioxide. J Supercrit Fluids. 2002;23(2):113-21. https://doi.org/10.1016/S0896-8446(02)00033-5

65. Bimakr M, Rahman RA, Taip FS, Ganjloo A, Salleh LM, Selamat J. Comparison of different extraction methods for the extraction of major bioactive flavonoid compounds from spearmint (Mentha spicata L.) leaves. Food Bioprod Process. 2011;89(1):67-72.

https://doi.org/10.1016/j.fbp.2010.03.002

66. Sanjaya RE, Tedjo YY, Kurniawan A, Ju YH, Ayucitra A, Ismadji $\mathrm{S}$. Investigation on supercritical $\mathrm{CO}_{2}$ extraction of phenolic-phytochemicals from an epiphytic plant tuber (Myrmecodia pendans). J CO $\mathrm{CO}_{2}$ Util. 2014;6:26-33.

https://doi.org/10.1016/j.jcou.2014.03.001

67. Chrastil J. Solubility of solids and liquids in supercritical gases. J Phys Chem. 1982;86(15):3016-21.

httsp://doi.org/10.1021/j100212a041

68. Del Valle JM, Aguilera JM. An improved equation for predicting the solubility of vegetable oils in supercritical $\mathrm{CO}_{2}$. Ind Eng Chem Res. 1988;27(8):1551-3. https://doi.org/10.1021/ie00080a036

69. Wang Y, Ying L, Sun D, Zhang S, Zhu Y, Xu P. Supercritical carbon dioxide extraction of bioactive compounds from Ampelopsis grossedentata stems: Process optimization and antioxidant activity. Int J Mol Sci. 2011;12(10):6856-70. https://doi.org/10.3390/ijms12106856

70. Hasler CM. Functional foods: Benefits, concerns and challenges - a position paper from the American Council on Science and Health. J Nutr. 2002;132(12):3772-81. https://doi.org/10.1093/jn/132.12.3772

71. Falk M. The impact of regulation on informing consumers about the health promoting properties of functional foods in the USA. J Food Sci. 2004;69(5):R143-5. https://doi.org/10.1111/j.1365-2621.2004.tb10726.x

72. Fernández-Rojas B, Hernández-Juárez J, Pedraza-Chaverri J. Nutraceutical properties of phycocyanin. J Funct Foods. 2014;11:375-92.

https://doi.org/10.1016/j.jff.2014.10.011

73. Knez Ž, Markočič E, Leitgeb M, Primožič M, Hrnčič MK, Škerget M. Industrial applications of supercritical fluids: A review. Energy. 2014;77:235-43.

https://doi.org/10.1016/j.energy.2014.07.044 
74. Herrero M, Cifuentes A, Ibañez E. Sub- and supercritical fluid extraction of functional ingredients from different natural sources: Plants, food-by-products, algae and microalgae: A review. Food Chem. 2006;98(1):136-48.

https://doi.org/10.1016/j.foodchem.2005.05.058

75. Sánchez-Camargo AP, Mendiola JA, Ibáñez I, Herrero M. Supercritical fluid extraction. In: Reedijk J, editor. Reference module in chemistry, molecular sciences and chemical engineering. Waltham, MA, USA: Elsevier; 2014. pp. 1-17. https://doi.org/10.1016/B978-0-12-409547-2.10753.X

76. Martillanes S, Rocha-Pimienta J, Cabrera-Bañegil M, Martín-Vertedor D, Delgado-Adámez J. Application of phenolic compounds for food preservation: Food additive and active packaging. In: Soto-Hernandez M, Palma-Tenango M, Garcia-Mateos MR, editors. Phenolic compounds - Biological activity. London, UK: IntechOpen; 2017. pp. 39-58. https://doi.org/10.5772/66885

77. Prasad $P$, Kochhar A. Active packaging in food industry: A review. IOSR J Environ Sci Toxicol Food Technol. 2014;8(5):1-7. https://doi.org/10.9790/2402-08530107

78. Kyle JAM, Duthie GG. 2006. Flavonoids in foods. In: Andersen ØM, Markham KR, editors. Flavonoids: Chemistry, biochemistry and applications. Boca Raton, FL, USA: CRC Press Taylor \& Francis Group; 2006. pp. 219-62.

79. Vicente-Vicente L, Prieto M, Morales Al. Efficacy and safety of quercetin as a food supplement. Revista de Toxicología. 2013;30:171-81 (in Spanish). Available from: http://www.redalyc.org/articulo.oa?id=91931189008.

80. Calderon-Montaño JM, Burgos-Morón E, Pérez-Guerrero C, López-Lázaro M. A review on the dietary flavonoid kaempferol. Mini Rev Med Chem. 2011;11(4):298-344. https://doi.org/10.2174/138955711795305335

81. Martínez-Flórez S, González-Gallego J, Culebras JM, Tuñón M. Flavonoids: Antioxidant properties and actions. Nutr Hosp. 2002;17(6):271-8 (in Spanish).
82. Deniz I, Ozen MO, Yesil-Celiktas O. Supercritical fluid extraction of phycocyanin and investigation of cytotoxicity on human lung cancer cells. J Supercrit Fluids. 2016;108:13-8.

https://doi.org/10.1016/j.supflu.2015.10.015

83. Cocero MJ, Martín Á, Mattea F, Varona S. Encapsulation and co-precipitation processes with supercritical fluids: Fundamentals and applications. J Supercrit Fluids. 2009; 47(3):546-55.

https://doi.org/10.1016/j.supflu.2008.08.015

84. de Paz E, Martín Á, Every H, Cocero MJ. Production of water-soluble quercetin formulations by antisolvent precipitation and supercritical drying. J Supercrit Fluids. 2015;104: 281-90.

https://doi.org/10.1016/j.supflu.2015.07.006

85. Lévai G, Martín Á, de Paz E, Rodríguez-Rojo S, Cocero MJ. Production of stabilized quercetin aqueous suspensions by supercritical fluid extraction of emulsions. J Supercrit Fluids. 2015;100:34-45.

https://doi.org/10.1016/j.supflu.2015.02.019

86. Yan M, Liu B, Jiao X, Qin S. Preparation of phycocyanin microcapsules and its properties. Food Bioprod Process. 2014; 92(1):89-97.

https://doi.org/10.1016/j.fbp.2013.07.008

87. Rashidi L, Khosravi-Darani K. The applications of nanotechnology in food industry. Crit Rev Food Sci Nutr. 2011;51(8): 723-30.

https://doi.org/10.1080/10408391003785417

88. Luo H, Jiang B, Li B, Li Z, Jiang BH, Chen YC. Kaempferol nanoparticles achieve strong and selective inhibition of ovarian cancer cell viability. Int J Nanomed. 2012;7:3951-9. https://doi.org/10.2147/IJN.S33670 